\title{
Research on the Influence of Group Counseling on Improving the Competence of College Psychological Committee Members
}

\author{
Cui Jia ${ }^{1, \text { a }}$, Xue Chunyan ${ }^{2, \text { b, * }}$ \\ ${ }^{1}$ Mental health education center, Wuhan University of Science and Technology, Wuhan, 430081, China \\ ${ }^{2}$ Mental health education center, Wuhan University of Science and Technology, Wuhan, 430081, China \\ aemail:985561663@qq.com, bivyxcy@163.com
}

Keywords: Group Counseling; Psychological Committee Member; Competence

\begin{abstract}
Psychological committee members must be equipped with certain knowledge, skills and personal qualities, which is the conclusion drawn from long-term theoretical research and practical experience. Based on the relevant research of the psychological committee members, this research carried out group counseling towards psychological committee members combined with the work characteristics and practice of the psychological committee members. The results showed that the competence of the psychological committee members after group counseling was significantly improved, and the organizational ability, work motivation, personality traits, work attitude, professional knowledge, and self-cognitive factors were significantly different.
\end{abstract}

\section{Introduction}

The psychological committee system is based on the current situation of the mental health of students in China's colleges and universities, and draws on the experience of peer counseling in the west and inherits the tradition of the national autonomous organization class committee. As early as 2004, Tianjin University took the lead in implementing the class psychological committee system in China. Zhan Qisheng and Li Yidan (2005) demonstrated the feasibility and necessity of setting up the position of student cadre through further investigation and research. In the following years, all colleges and universities across the country have set up psychological committee positions in their classes, and actually experienced the positive effect of the psychological committee system on the education system of mental health in colleges and universities, reflecting the effective application of the psychological committee system in practice.

While playing a role that cannot be ignored, the psychological committee members have encountered many problems in the actual work. Since the psychological committee members are all selected from the students, they have not systematically studied the knowledge and skills related to psychology, and cannot work effectively. Some psychological committee members do not have a clear and scientific understanding of job responsibilities and mental health education work. They can neither know how to carry out work effectively, nor do they raise the awareness of taking the initiative to carry out work, and only thing they did is passively cooperated with teachers to carry out propaganda work. Therefore, how to improve the competence of psychological committee members is a priority in the work and research of mental health education in colleges and universities.

Group counseling is an effective way to help people in college. This research attempts to use the college psychology committee's competence model as a guide to conduct group counseling for psychological committee members to help the them master work skills, understand psychological knowledge, improve their comprehensive quality, and help them better carry out mental health education. 


\section{Objects and Methods}

\subsection{Objects}

A notice was published in the psychological committee work group of a university in Wuhan to recruit research subjects, and students volunteered to sign up. The enrolled students were interviewed and 16 psychological committee members without obvious mental disorder were recruited, among which 6 were male and 10 were female.

\subsection{Method}

\subsubsection{Research ideas}

This research adopted the repeated measurement design approach. The subjects received group counseling once a week for about 2 hours each time for a total of 6 weeks. Before the first group counseling and after the last group counseling, the subjects were asked to fill in the Psychological Committee Members' Competence Force Table, and the questionnaire was collected on the spot to analyze the difference in scores between the pre-and post-counseling to determine the influence of group counseling on the psychological committee members' competence. After each group counseling, the Sunflower Growth Log should be filled in to collect the subjects' subjective feelings of participating in the group counseling.

\subsubsection{Intervention process}

Table 1 Group counseling program

\begin{tabular}{|c|c|c|c|}
\hline Theme & Goal & Process & Homework \\
\hline $\begin{array}{l}\text { 1.Team } \\
\text { Building }\end{array}$ & $\begin{array}{l}\text { Group members get to know } \\
\text { each other, make group } \\
\text { contracts, and experience } \\
\text { teamwork. }\end{array}$ & $\begin{array}{l}\text { 1. Game of Strong wind; } 2 . \\
\text { Self-introduce; } 3 \text {. Discuss } \\
\text { and make a group contract; } \\
\text { 4. Solving thousands of } \\
\text { knots skillfully; 5. Journey } \\
\text { of trust; } 6 \text {. Confirm guardian } \\
\text { angels. }\end{array}$ & $\begin{array}{l}\text { Read Handbook } \\
\text { Psychological } \\
\text { Committee Work. }\end{array}$ \\
\hline $\begin{array}{l}\text { 2.Cognitive } \\
\text { Module } 1\end{array}$ & $\begin{array}{l}\text { Learn communication, } \\
\text { listening skills and basic } \\
\text { mental illness recognition } \\
\text { skills. }\end{array}$ & $\begin{array}{l}\text { 1. Human chair; 2. Communication } \\
\text { training; 3. Practice listening. } 4 . \\
\text { Talk about the "differences" around } \\
\text { me. }\end{array}$ & $\begin{array}{l}\text { Learn the symptoms of } \\
\text { mental illness. }\end{array}$ \\
\hline $\begin{array}{l}\text { 3.Cognitive } \\
\text { Module } 2\end{array}$ & $\begin{array}{l}\text { Consolidate knowledge about } \\
\text { mental illness, build good } \\
\text { self-cognition and develop } \\
\text { self-confidence. }\end{array}$ & $\begin{array}{l}\text { 1. Guess the symptoms; 2. My } \\
\text { self-portrait; 3. Guess who it is; } 4 \text {. } \\
\text { Three advantages; 5. I'm made for } \\
\text { something. }\end{array}$ & $\begin{array}{l}\text { Ask friends what } \\
\text { advantages you have } \\
\text { and practice } \\
\text { self-encouragement } \\
\text { every day. }\end{array}$ \\
\hline $\begin{array}{l}\text { 4.Emotion } \\
\text { Module }\end{array}$ & $\begin{array}{l}\text { Learn to recognize emotions } \\
\text { and master the way to } \\
\text { regulate emotions, learn } \\
\text { empathy. }\end{array}$ & $\begin{array}{l}\text { 1. Smile and shake hands; } 2 . \\
\text { Perform emotions and recognize } \\
\text { emotions; } 3 \text {. Share a mood } \\
\text { barometer for the week; } 4 \text {. } \\
\text { Introduction and application of } \\
\text { ABC theory of emotion; } 5 \text {. Empathy } \\
\text { exercises. }\end{array}$ & $\begin{array}{l}\text { Chat with } 3 \text { classmates, } \\
\text { experience each other's } \\
\text { feelings, and respond. }\end{array}$ \\
\hline $\begin{array}{l}\text { 5.Behavior } \\
\text { Module } 1\end{array}$ & $\begin{array}{l}\text { Discuss and analyze the } \\
\text { psychological committee } \\
\text { members' practical problems. }\end{array}$ & $\begin{array}{l}\text { Psychological committee case } \\
\text { supervision meeting }\end{array}$ & Rehearsal psychodrama \\
\hline $\begin{array}{l}\text { 6.Behavior } \\
\text { Module } 2\end{array}$ & $\begin{array}{l}\text { Make a plan for your future } \\
\text { work and say goodbye. }\end{array}$ & $\begin{array}{ll}\text { 1. Relax and beat; } & 2 . \\
\text { Psychodrama performance; } & 3 . \\
\text { Discuss the content and help } & \\
\text { methods of psychodrama; } & 4 . \\
\text { My work plan; } & 5 . \\
\text { Looking for guardian angels. } & \end{array}$ & $\begin{array}{l}\text { Conduct a group } \\
\text { activity in the class }\end{array}$ \\
\hline
\end{tabular}


Based on the existing research conclusions of psychological committee members, this research designed a group counseling program combined with the work characteristics and practice of psychological committee members. In group counseling, psychological committee members with the same status, common problems and growth needs worked together in a group for 6 weeks.

The goal of group counseling is to help members understand the responsibilities of psychological committee member, master necessary mental health knowledge, learn to carry out mental health education work among students, master basic skills to communicate with classmates, such as empathy, listening and communication skills, and know how to understand and help others. Besides, the significance of group counseling also lies in promoting self-understanding and growth, establishing good self-cognition, and learning ways to regulate emotions and help others and yourself. Last, it aims to apply the experience of group counseling to the work of psychological committee members, carry out peer group counseling among students, and promote the development of psychological health of college student's education.

Group counseling is mainly divided into three modules: cognitive module, emotional module and behavior module. The cognitive module helps psychological committee members to understand the symptoms of mental illness, learn communication and listening skills, and at the same time, establish good self-cognition and build confidence to carry out the work of members. The emotion module helps psychological committee members to recognize emotions, regulate emotions, and learn empathy skills. The behavior module includes a psychological committee case supervision meeting, which discusses and supervises the problems encountered by the psychological committee members in actual work, presents the student cases encountered in reality through psychodrama, discusses the countermeasures, and helps the psychological committee members to make plans for future work.

The specific content of group counseling is shown in table 1.

\subsubsection{Tools}

(1) Questionnaire about college psychological members' competence

The questionnaire was compiled by Yi Sijia through various methods such as open questionnaire and behavioral event interview, including seven dimensions of organizational ability, self-cognition, work motivation, team cooperation, personality traits, work attitude and professional knowledge. The questionnaire has good reliability and validity; all the indicators can meet the measurement standards, and can be used for the assessment of psychological committee members' competence. The questionnaire has 42 questions, and the higher the score, the stronger the competency.

(2) Sunflower growth log

It is a self-made questionnaire that members are required to fill out after each group counseling to understand their feeling of participating in the group counseling and self-assessment on their growth. It includes feedback on the overall situation of group counseling, group atmosphere, instructors, partners, participants' gains and performance, and an open response to group coaching content, feelings and suggestions.

\subsubsection{Leaders and their training background}

The leader of group counseling is a full-time teacher of mental health education in colleges and universities, with a master degree in psychology. He has carried out group counseling for many times and with rich experience in psychological theory and mental health education work. Another assistant is a second-year graduate student majored in Social Work Profession.

\section{Results}

The paired sample $t$ test was performed for the pre-test and post-test scores, and the results were shown in table 2.

As can be seen from Table 2, before and after group counseling, the competence scores of members have changed significantly. Apart from the team cooperation, the scores of all factors are higher after group counseling than before group counseling. Among them, the differences in 
organizational ability, work motivation, personality trait, work attitude and professional knowledge are very significant $(\mathrm{P}<0.01)$, the differences in self-cognitive factors are significant $(\mathrm{P}<0.05)$, and the differences in total scores of competency are very significant $(\mathrm{P}<0.01)$. These results indicated that group counseling dramatically improved the competence level of psychological committee members.

In the sunflower growth log, participants reported that "the skills and methods of communication have been learned in group counseling, and I will try to use it." "I saw that everyone has their own advantages, but without eyes to find them." "The friends are so great, I really learned a lot from them." "I know more clearly what I should do as a psychology committee member".

Table 2 Comparison of competence scores of participants before and after group counseling

\begin{tabular}{llll}
\hline & $\begin{array}{l}\text { before group } \\
\text { counseling }\end{array}$ & $\begin{array}{l}\text { after group } \\
\text { counseling }\end{array}$ & $\begin{array}{l}\text { T test of the pre-test and } \\
\text { post-test differences }\end{array}$ \\
\cline { 2 - 3 } $\mathrm{M} \pm \mathrm{SD}$ & $\mathrm{M} \pm \mathrm{SD}$ & \\
\hline $\begin{array}{l}\text { Organizationa } \\
\text { l Ability }\end{array}$ & $24.00 \pm 3.18$ & $25.19 \pm 3.19$ & $-3.230^{* *}$ \\
\hline Self-cognition & $32.13 \pm 2.58$ & $32.88 \pm 2.25$ & $-2.535^{*}$ \\
\hline $\begin{array}{l}\text { Work } \\
\text { Motivation }\end{array}$ & $27.69 \pm 3.55$ & $28.75 \pm 3.26$ & $-3.437^{* *}$ \\
$\begin{array}{l}\text { Team } \\
\text { Cooperation }\end{array}$ & $20.44 \pm 1.90$ & $20.81 \pm 2.07$ & -2.087 \\
$\begin{array}{l}\text { Personality } \\
\text { Trait }\end{array}$ & $18.81 \pm 2.85$ & $19.38 \pm 2.73$ & $-3.093^{* *}$ \\
$\begin{array}{l}\text { Work Attitude } \\
\text { Professional }\end{array}$ & $18.62 \pm 1.96$ & $19.25 \pm 1.84$ & $-3.101^{* *}$ \\
$\begin{array}{l}\text { Knowledge } \\
\text { Total Scores }\end{array}$ & $157.69 \pm 15.80$ & $16.06 \pm 2.77$ & $-3.691^{* *}$ \\
\hline & & & \\
\hline
\end{tabular}

\section{Discussion}

Based on the above data analysis results, we can see that psychological committee members' competence level has been greatly enhanced after participating in group counseling. Through participating in this targeted group counseling activity, they are no longer in a state of groping their own way of work, no longer doubting the importance of their work. In contrast, they have a clearer understanding of the duties of their work, more work skills and psychological knowledge, and a bright understanding of the future work.

The results of this research also show that group counseling is an effective training method for psychological committee members. In this group counseling, many designed links have not only helped the psychological committee members improve their work skills but also are conducive to their growth. The psychological committee members themselves have good psychological qualities and are necessary prerequisites for them to carry out mental health work in the class. The psychological committee's way of thinking, emotional process, coping style, etc., will affect their level of dedication, effort and job performance in the class mental health education work. Group counseling is vivid and experiential. Psychological committee members experience trust and cooperation in group counseling, freely express their thoughts and feelings, learn from each other, explore common problems, and discuss solutions. The psychological committee members supported each other and shared with each other in group counseling, which produced a strong sense of team identity and belonging.

In addition, through the process of experiencing group counseling, the psychological committee members will have a deeper understanding of group counseling, which will help them to carry out peer group counseling in the class in the future. The peer group counseling rules are relatively simple and easy to master. The psychological committee members can apply the skills they have learned in group counseling to peer group counseling, and transfer their experience in group 
counseling to future activities, so that more students can benefit from it.

\section{Acknowledgement}

In this paper, the research was sponsored by university student work quality project Construction and Practice Exploration of the Staff Psychological Committee Training System (project number: 2018XGJPX3026) and 2018 teaching research project of Wuhan university of science and technology Application Research of Positive Psychology in the Practice Teaching of College Students' Mental Health Education (project number: 2018X063).

Notes: This paper is the phased achievement of 2018 general funding project of Hubei province

\section{References}

[1] Fan Fumin. Group Psychological Counseling[M]. Higher Education Press, 2005.

[2] Huang Qiaorong. Investigation and Analysis of the Status Quo of College Class Psychological Committees [J]. Chinese Journal of Health Psychology, 2008 (10).

[3] Li Li. A Review of the Research on the Domestic Psychological Committee System [J]. Journal of Jiangxi University of Science and Technology, 2011 (02).

[4] Li Xiaoran. Reflections on the Construction of College Psychological Committee System[J]. Journal of Inner Mongolia Normal University, 2009 (3).

[5] Liu Yanjun. The Use of Group Counseling in Increasing the Initiative of College Psychological Committee Members[J]. Education and Teaching Forum, 2011 (5).

[6] Yi Sijia. Competency Model Construction and Questionnaire Compilation of College Psychological Committee Members [D]. Jiangxi Normal University, 2014.

[7] Yao Xiaoyan. Theoretical Thinking and Practical Exploration of Setting up Class Psychological Committees in Colleges and Universities[J]. Journal of Guizhou Normal College, 2010 (11). 